\title{
TEACHING TECHNIQUES APPLIED IN SENIOR HIGH SCHOOL FOR STUDENTS WITH SPECIAL NEEDS (SMALB)
}

\author{
Susilowati*, Puji Sri Rahayu** \\ Program Studi Tadris Bahasa Inggris Fakultas Tarbiyah dan Keguruan \\ IAIN Antasari Banjarmasin \\ Susioppo123@gmail.com; p.rahayu@gmail.com \\ * Mahasiswa Prodi Tadris Bahasa Inggris \\ ** Dosen Prodi Tadris Bahasa Inggris
}

\begin{abstract}
Teaching English as a foreign language to students with special needs is somewhat different of those mainstream students. The teachers may face lots of difficulties and therefore, they must apply different techniques in teaching the students. The goal of this study is to figure out the techniques applied for Teaching English to students with special educational needs. This study is conducted in a Senior high school for students with special needs (SMALB) in Banjarmasin, South Kalimantan. The study is based on classroom observations and interview with the English teacher. The findings conclude that teacher applied six different techniques in teaching English as follow; (1) transcription, (2) Question and Answer, (3) Repetition Drill, (4) Reading Aloud, (5) Memorization and (6) Reading aloud.
\end{abstract}

Keywords: students with special educational needs, teaching techniques, english as a foreign language

\section{INTRODUCTION}

In the past few decades, it is commonly to see the children with special needs ( those who suffered from mental retardation or physical handicapped) go to school as they also have the right to have the same education as other children. The children with special needs go to special school for special needs. It is mentioned in the law of national educational system section 15 year 2003 that education are divided into some categories; general education, vocational, academic, profession, religion, and distinctive education. Distinctive education is a kind of education for the students who have difficulties in attending the learning process due to some physical, emotional, mental, intellectual, and social disability, or perspicacity potential and special talent (Labpuguh, 2015).

SLB (Sekolah Luar Biasa) is in the category of distinctive school. There are some types of SLB based on the need of the students such as Tuna Netra (blind), Tuna Rungu (deaf), Tuna Grahita (mental retardation), and Tuna Daksa (physical disabilities). The school in SLB is not different to regular school. it started from Kindergarten, Elementary School, Junior High School and Senior High School. In SLB (Sekolah Luar Biasa), Kindergarten is TKLB, Elementary School is SDLB, Junior High School is SMPLB, and Senior High School is SMALB.

Students in SLB also learn the same subjects as the students in regular schools. The English language is taught in SLB in Indonesia to introduce foreign language or basic knowledge for the students. Teaching English as foreign language requires certain method and techniques. People may think that it will be very different the techniques of teaching English in regular schools and SLB. Technique, in teaching a specific procedure for carrying out a teaching activity, such as the ways a teacher corrects students' errors or sets up group activities, Richard and Schnidt (2010, p.590). Therefore, this study aims to figure out teaching techniques applied by the teacher in teaching English in SLB. 


\section{Students with Special Need}

Disability or unable doing certain things related to mentality as well as physicality defines as any restriction or lack of ability to perform an activity in the manner or within the range consider normal for human being. freedictionary (2015, cited in Houghton Mifflin Harcourt Publishing Company, 2011) disabled in clear preference in contemporary American English in referring to people having either physical or mental impairments, with the impairments themselves preferably termed disabilities. Thus the students with special need are they who need some guidance and encouragements to motivate their interest in learning.

Students with special needs or well known as disabled in everyday conversation connected with condition that deviates from general average that the students have some impairment in a certain part of their body, i.e. sight impairment, hearing impairment, developmental impairment, physic impairment, maladjustment"s behaviour impairment, autistic, and hyperactive impairment.

There are some categories of disability in Indonesia that according to Delphi (2009) can be categorized as:

1. Children with sight impairment and people who have this impairment are called blind. In Indonesia blind is known as Tuna Netra. It is the impairment that the children are total blind and cannot use their vision to see what is displayed before them and to follow teaching and learning activity in daily life.

2. Children with hearing impairment and people for this impairment are called as deaf that in Indonesia well known as Tuna Rungu, where the children are hard to hear or use their hearing or deaf, by the cause of the difficulties in hearing, the ability in speaking becomes difficult, on the other hand, the ability in hearing is based on the hearing of people.

3. Children with developmental impairment or mental retardation in Indonesia is called as Tuna Grahita. Mental retardation is children that have learning problems which is caused delaying the developing intelligence, mental, emotional, and social.

4. Children with physical impairment or physically impaired in Indonesia is called Tuna Daksa are children that have physical abilities which the impairment is by their physical like part of their body such as their bones.

5. Children with maladjustmente ${ }^{\text {es }}$ behavior impairment or maladjustment disorder in Indonesia is called as Tuna Laras. Children with this impairment are the children that have emotional or behavioural disorder, that their characteristic is much bulge than normal children that they overdo over something and cannot control their behaviour.

Methods and techniques of teaching English:

\section{Grammar Translation Method}

Daniel Larsen Freeman (2000) said that Grammar Translation Method is a classical method that in early century, Grammar Translation Method was used for the purpose of helping of students read and appreciate foreign language literature, it was also hoped hat through the study of grammar of the target language, students would become more familiar with the grammar.

There are some techniques in grammar translation method which mention as follows:

a. Translation of literary passage

In this technique, students are asked to translate some reading passages which is came by several form such the statement before like dialogue, lyrics, synopsis, movie etc. into target language where the students should not translate the text literally, but rather in a way that the students understand the meaning they are translated.

b. Comprehension question

Based on to Whyte (2005), in comprehension question, there are three types which the first is questions to test the students ${ }^{\text {ee }}$ comprehension of the text, second is questions whose answers are not in the text, 
but which call upon the students ${ }^{\text {ee }}$ deduction skills.

\section{c. Memorization}

Students are given some lists of target language vocabulary words along with the translation or the source of language where they are asked to memorize all the vocabulary given. Besides that the students are also given some shorts of grammar.

\section{Direct Method}

Direct method is a method that called as a natural method. It is discovering the importance of speaking which in applying the method using English in everyday spoken language, on the other hand student learns by associating meaning directly in English. Below are some techniques those are included in direct method:

\section{a. Reading aloud}

According to Alderson (2000), reading is a process of communication between the writer and the reader. The writer expresses his/her idea in the form of writings and the reader tries to get the information or the message by reading it. Reading aloud to learners at the early stage would therefore restore that integrity and present larger semantic units which would lead to better understanding (Dhaif, 1990).

b. Question and answer exercise

Based on to Cotton (1988, p. 1), question is any sentences which has an interrogative form or function. It focuses on the relationship between teachers' classroom questioning behaviours and a variety of student outcomes. Cotton also said that questions and answer could develop interest and motive students to become actively involve, and could review and summarize previous lesson. Freeman (2000) stated that question and answer exercise is an activity where the students are given some questions and answer in full sentence which contain some grammatical structures and new words so that they practice the new words and grammatical at the same time.

c. Dictation
Moris (1983) asserted dictation is an activity in writing down words spoken by teacher, a learning activity through which students are encourage to develop accuracy in both listening and writing. probably regard dictation as an ,old fashion ${ }^{\text {ee }}$. The exercise tended the traditional format, on the other hand the activity is by the teacher read a passage to the students phrase by phrase and the students copied the passage and somehow the writing got corrected.

\section{Audio Lingual Method}

Based on Chen (2015), Audio Lingual Method was based onstructural linguistics and behavioral psychology. In other words the way acquires the sentence patterns of target language is repetition of dialogues about everyday situation that are imitated and drilled to make the response automatic. Basically, the principle of audio lingual method for the lines of dialogue it uses drills to teach.

a. Dialog memorization

The activity of dialog memorization is by making dialogues or short conversation between two people and the dialog is memorized by the students to take the role from the dialog. After learning one person ${ }^{\text {ee }} \mathrm{s}$ line, students switch role and memorize the other person "s part. After the dialog has been memorized, teacher pairs the students to perform the dialog (Freeman. 2000).

b. Repetition drill

According to Baker and Westrup (2003), in repetition drill, students repeat language the teacher has presented as accurately as possible. Brook, (1960, and Politzer, 1968, cited in Ikhsan, 2013) noted that practice with drill helps learners improve their language proficiency. In repetition drill students take order to repeat some short of reading in form of dialogue, passage, etc.

\section{Silent Way}

In one sense, the silent way was too harsh method and the teacher was also too distant to encourage a communication atmosphere. The teacher provided single word stimuli, short phrases and sentences, once or twice, and then the students refine 
their understanding and practicing pronunciation among themselves with minimal corrective feedback from the teacher. (Brown, 2000, p. 29) In other words, the interaction of the students and teacher can be said as lack of communication, students have their courage to be active while the teacher manages to pay to the students $^{\text {ee }}$ action or interaction during the class activity in order to make the students active among students to the students.

These following techniques are categorized as the technique of silent way according to Freeman (2000):

a. Teacher silent

The teacher gives just as much help as is necessary and then is silent. Or the teacher sets up an unambiguous situation, puts a language structure into circulation (for example, „Take a rod $^{\text {ee}}$, and then is silent. Even in error correction, the teacher will only supply a verbal answer as a last resort.

\section{b. Peer correction}

Students are encouraged to help other students they are experiencing difficulty. It is important that any help be offered in a cooperative manner, not a competitive one. The teacher monitors the aid so that it is helpful, not interfering.

\section{Suggestopedia}

According to Zulfiqar (2012) Suggestopedia is the application of suggestion in pedagogy where learners experience feelings of failure can be eliminated. In applying the method, teacher arranges the classroom which the students sit on the couch in a half circle with dim lighting, some posters associated with the learning material is posted on the wall. The teacher greeted the students in mother tongue then plays classical music to make the students relax by sighing breath several times slowly and instruct students to imagine about the material being studied. When students open their eyes, teacher asks them to play role while the teacher being narrator as music plays, and there is no homework given. Some techniques below are parts of suggestopedia according to Freeman (2000) :

63

\section{a. Classroom set-up}

The challenge for the teacher is to create a classroom environment which is bright and cheerful. This was accomplished in the classroom we visited where the walls were decorated with scenes from a country where the target language is spoken. These conditions are not always possible. However, the teacher should try to provide as positive an environment as possible.

b. Role play

Students are asked to pretend temporarily that they arc someone else and to perform in the target language as if they were that person. They are often asked to create their own lines relevant to the situation. In the lesson we observed, the students were asked to pretend that they were someone else and to introduce themselves as that person.

\section{c. Positive suggestion}

It is the teacher's responsibility to orchestrate the suggestive factors in a learning situation, thereby helping students break down the barriers to learning that they bring with them.

d. Singing Song

According to Shen (2009) song is a combination of music and lyrics, possesses many intrinsic merits, such as a kaleidoscope of culture, expressiveness, excitability and therapeutic functions, which render it an invaluable source for language teaching. Shen (2009) also added EFL learners will get familiar with and internalize them through repetition and imitation. Songs are useful for freeing the speech muscle and evoking the positive emotion. Students play rhythmic instrument as they sing a song (Freeman, 2000).

\section{Community Language Learning}

Curran (1972, cited in Brown, 2000) asserted that CLL in which learners in classroom they were not just as a "class" but as a "group", a group in need of certain therapy and counselling. In the class, students seated in circle with the teacher outside of the circle. The class activity begun by the activity of translation from native language to target language (English) in which the teacher voiced it and the students repeat. Besides that, the students are allowed to share their 
learning experience to get to know one another to build community. The activity of the conversation was taped for later listening at the end of each session.

\section{a. Transcription}

In this technique teacher writes the L1 equivalent of the text in the target language and the students copy them in their notebooks (Curran, 2008).

b. Reflection in experience

According to Freeman (2000, p 104), The teacher takes time during and/or after the various activities to give the students the opportunity to reflect on how they feel about the language learning experience, themselves as learners, and their relationship with one another. As students give their reactions, the teacher understands them-shows that he has listened carefully by giving an appropriate understanding response to what the student has said. He does not repeat what the learner says, but rather shows that he understands its essence.

\section{Total Physical Response}

In the total physical response classroom, students did a great deal of listening and acting (Arifin S. P. 24). According to Politeracy (2015, p. 1), TPR is a teaching technique that enable students to acquire new English vocabulary by listening to and carrying out spoken commands. In TPR activities students are not required to speak, the tutor models commands and continually repeats and review them until the students can carry the commands with o difficulty.

a. Using commands

It should be clear that using command is a technique which is applied some commands to the students to do an action. In this technique, the commands are given to get students to perform some actions which the commands aim to make the meaning clear and easy to understand (Freeman, 2000).

b. Role reversal

Students command their teacher and classmates to perform some actions. Asher says that students will want to speak after ten to twenty hours of instruction, although some students may take longer. Students should not be encouraged to speak until they are ready (Freeman, 2000).

c. Action sequence

According to Freeman (2000), at one point we saw the teacher give three connected commands. For example, the teacher told the students to point to the door, walk to the door, and touch the door. This series of commands is called an action sequence.

\section{Communicative Teaching}

Community Language Learning is a technique in which students work together to develop what aspects of a language they would like to learn. The teacher acts as a counselor or knower while the learner acts as a collaborator (client), although sometimes this role can be changed. This is also known as the Counseling-Learning method (Richard and Rodger, 1986). Some of the techniques are:

a. Authentic Materials

Authentic materials are any materials that exist in real world for native speakers in English. For example like newspapers and advertisement, official letters, etc. that this is use the actual text or document as it is in real life and modify it so the learners can use it successfully (Freeman, 2000).

b. Scrambled sentences

According to Nahrkhalaji (2014), in scramble sentence students are given a passage in which the sentence are in the scramble order. Students are asked to unscramble the sentences so that the sentences are stored to their original order, learning coherence and cohesive.

c. Language games

To see by the students ${ }^{\text {ee }}$ interest, most of students which more than half students ${ }^{\text {ee }}$ of some schools enjoying games whenever they learning languages which means it is one of successful ways to gain the intention of the students while class activity is being held and when the game are designed properly (Freeman, 2000).

d. Picture strip story

Nahrkhalaji (2014) said that picture strip story is a technique where the a students in one group is given a strip story then show 
pictures to the other students in the group and asks them to predict the next pictures. The activity is by describing and an example of using problem solving task as communicative technique.

d. Role play

Sometimes in some event psychologies and social is difficult to explain by words which is why role play is needed in this case to make the students are all participated in some role and it slightly making the class alive and enjoyable. This technique shows the role of students they are lead which in each role they get to know the behavior, facial expression of their role and also the point of their story or plot they are in (Freeman, 2000, p.134).

\section{METHOD}

The approach of this research is using qualitative approach. The writer aims to describe the situation, the daily process of teaching and learning in the class to see the technique used in teaching English. The data was collected through classroom observations and interview. The researcher observed the classes for 12 meetings. The setting of this research is in SMASLB B/C Dharma Wanita Persatuan Provinsi Kalimantan Selatan. The Subject of thus research is the English teacher and 26 students at SMALB in SLB B/C Dharma Wanita Persatuan Provinsi Kalimantan Selatan. After the data were collected and processed, and they were analysed by using descriptive qualitative analysis; the problems is classified and connected by other problems those are found in research. The analysis helps the writer to highlight some important conclusion from this research. The conclusions are taken inductively.

\section{FINDINGS}

Based on the data the researcher got from interview and observation, the researcher found the techniques the teacher used to teach English:

\section{a. Transcription}

Transcription was technique which the most frequently used by the teacher, it was ten times the teacher applied during the 65 observations the researcher took the research. During the observation, the researcher saw that the teacher wrote the material that they would be discussed, and the while the teacher wrote, the students copied the material she wrote on their book. There was also the time when the teacher wrote and finished the material on the whiteboard she explained and did some other activities which at the end of the session, the teacher asked them to wrote what she had written on their book. It supported Curran "s (2008) statement which was noted that in this technique teacher writes the L1 equivalent of the text in the target language and the students copy them in their notebooks.

b. Reading aloud

Reading is a process of communication between the writer and the reader. The writer expresses his/her idea in the form of writings and the reader tries to get the information or the message by reading it, Alderson (2000). Reading could possibly train the studentse memorization and fluency, because it train eyes to see the word and symbols, and tongue to speak, with reading aloud brain could work fast. The teacher said during the interview: "mereka memang harus sering sering dilatih untuk membaca supaya menggerakkan lidah mereka agar terbiasa".

Based on the observation, the teacher applied the reading aloud in two classes. The first thing she did was reading the material or the vocabularies which were written by herself on the whiteboard in order to give the example to the students of pronunciation to the students while the students were listening to what the teacher read. It supported by Gibson"es (2008) idea about reading aloud that before asking the students to read the teacher read the text to give a good example in pronunciation. It also similar to Amer (1997) which showed that the learners had better understanding of what they were reading in the teacher reading aloud situation. After the teacher"s reading session was done, she asked the students to read the material she had prepared. The text or the vocabularies which were displayed on the whiteboard were read by the student out loud in order to make the other students in the 
class heard what she/he read. By reading aloud, the students could train their tongue to pronounce the words and to accustom the students with English pronunciation by reading. From the interview the researcher with the English teacher, she said that in reading aloud she aimed that the students could pronounce and used to with the English words which were foreign for them. It is obvious the fact that reading aloud can help the students practice pronunciation. Gibson (2008) said that by using reading aloud students can be focus on the text and by practicing them the words will flow in as natural sounding a manner as possible.

c. Repetition drill

In the interview with the teacher, she said "sebagian dari siswa disini memiliki banyak kesulitan dalam membaca, makanya saya biasanya mengajak mereka untuk mengikuti saya". From here, the researcher found that the repetition drill was applied by the teacher six times in six classes. In applying repetition drill, the teacher read the text she had prepared to the students which were displayed on the whiteboard, and on the book in class X B. The teacher led or guided the students reading the material. She read the text little by little and the students follow what she had said. It is supported by the statement of Baker and Westrup (2003, p.71) in repetition drill, students repeat language the teacher has presented as assurately as possible.

The teacher reread the material that the students had read several times in order to make the students remember and familiar with the words they are reading. Repetition drill which meant repeating text several times or drilling practice is affected to improve students $^{\text {ee }}$ language expertise. Brook (1960) and Politzer (1968) cited in Ikhsan (2013) note that practice with drill helps learners improve their language proficiency.

\section{d. Memorization}

Memorizing is the activity of thinking and process information to people $\mathrm{s}$ brain where all human did it sometimes without they know and sometimes realize it. (Baddeley, 2000) stated that people think with their working memory which is define as small amounts of information accessible over short times that people can use in learning and thinking.

This technique was applied by the teacher in the fourth observation, in the teaching and learning English she taught her students. In memorization the teacher asked the students to memorized the material she gave on the whiteboard and she gave a little times for the students to memorize it that after time to memorize were over, the teacher began to asked some questions about the material or the words they memorized a moment ago. This is appropriate to the statement by Freeman (2000, p.20) Students are given some lists of target language vocabulary words along with the translation or the source of language where they are asked to memorize all the vocabulary given. Besides that the students are also given some shorts of grammar.

e. Questions and answer

From observation in several classes, the researcher discovered that in teaching English by questions and answer, a few questions are related to the material which the questions were from the material displayed on the whiteboard, and there were also some questions which were not on it but also related to the material. Cotton (1988, p.1) said that question is any sentences which has an interrogative form or function. It focuses on the relationship between teachers' classroom questioning behaviours and a variety of student outcomes. In teaching and learning English activity when the technique she was applied questions and answer, the class seemed alive and the students were cheered.

Richards and Charles Lockhart ((2000) as cited in Shi-Ying, 2011) noted in some classrooms over half of class time is taken up by questions and answer exchanges. In the interview the teacher said that "biasanya kalau saya membawakan materi yang berkaitan dengan kosa kata seperti binatang, buah - buahan, dan saya mengajak mereka dengan sedikit bertanya jawab, siswa dengan antusiasnya merespon".

f. Singing Song 
Singing is a common technique the teacher used in teaching English which all ages and gender can and like to do it. Through singing and the lyrics teacher can serve the idea that wants to show to students be able to accept by them in easy and funny ways. In the fifth observation, the teacher applied this technique in teaching English. At first, she gave the lyric to the students and using this lyric, the teacher and the students sing it together. Through the lyric the teacher presented the point she wanted the students to understand. The teacher presented the lyrics (vocabularies on the whiteboard) and she sang it as the example the students could watch and imitated the tone she sang. It supported by the statement of Shen (2009, p. 92) which said EFL learners will get familiar with and internalize them through repetition and imitation.

In the interview, the English teacher said that the students liked the fun technique like singing. She said "mereka sangat senang kalau tehnik yang dipakai asyik, seperti di pertemuan sebelumnya mereka ingin bernyayi tanpa harus ditunjuk".

\section{CONCLUSION}

In addition, to conclude, Singing is the technique that the most frequently used by the teacher followed by transcription. This technique was appeared in almost every meeting.

\section{REFERENCES}

Alderson, J. Charles. 2000. Assessing Reading. Cambridge: Cambridge University Press. Retrieved September $22^{\text {nd }} 2015$.

Amer, A. 1997. The Effect of the Teacher's Reading Aloud on the Reading

Comprehension of EFL students. ELT Journal Vol. 51 No.1 September $16^{\text {th }}$ 2015.

Baddeley, A. 2000. Short-term and working memory. In E. Tulving and F.I. M. Craik, (Eds). The Oxford Handbook of Memory. New York, N.Y.: Oxford University Press.
Baker, J and Westrup, H. 2003. Essential Speaking Skills. London and New York: Continuum.

Brown H. D. 2000. Teaching by Principle An Interactive Approach to Language Pedagogy Second Edition. San Fransisco: Longman

Brown H. D. 2007. Principle of Language Learning and Teaching. San Fransisco: Longman

Brown H. D. 2010. Language Assessment Principle nd Classroom Practices. New York: Pearson Education

Chen, Chiffen. 2015. The Audio Lingual Method. Retrieved October $24^{\text {th }} 2015$

Cotton, Kathleen. 1988. Classroom Questioning. United Stated: North West Regional Educational Laboratory. Close up No. 5. Retrieved October $15^{\text {th }} 2015$.

Dewi. N.K.N. 2013. Teaching descriptive paragraph writing By using direct method to the eighth Grade students of smp pgri 9 denpasar in Academic year 2013/2014.

Retrieved October $28^{\text {th }} 2015$

Delphie, Bandi. 2006. Pelajaran Anak Berkebutuhan Khusus dalam Setting Pendidikan Inklusi. Klaten: PT. Intan Sejati Klaten.

Dhaif, H. 1990. Reading Aloud for Comprehension: A Neglected Teaching Aid. Journal Reading in a Foreign Language Vol. 7 No. 1. Retrieved September $29^{\text {th }} 2015$.

Freeman, D.L. 1990. Language Teaching Methods Teacher Handbook for The Video Series. Wahinton D.C.: United States Departement of State

Freeman, D.L. 2000. Technique and Principles in Language Teaching Second Edtion. New York: Oxford University Press

Gravity. 2008. Community Language Learning (CLL). ELT Method. WordPress.com Retrieved November $7^{\text {th }} 2015$.

Gyi, Ko Ko. 1994. Teaching English As a Second Language - The Silent Way. 
Journal article. Vol.14 No.3. Retrieved October $24^{\text {th }} 2015$.

Hamiloglu, Kamile. 2012. The Impact of Teacher Questions On Student Learning in EFL. Retrieved November $02^{\text {nd }} 2015$.

Ical Tefl. 2015. Eer Correction in English Language Teaching. Retrieved November, $08^{\text {th }} 2015$.

Ikhsan, Hery K. A. 2013. Applying Drills to Improve Language Proficiency. The Ryukoku Journal of Humanities and Sciences vol.34 No.2. Retrieved November $2^{\text {nd }} 2015$.

Kidd, Richard. 1992. Teaching ESL Grammar trough Dictation. Retrieved October $28^{\text {th }} 2015$.

Labpuguh. 2015. SLB dan Sejarah Pendidikan Luar Biasa. Wordpress.com Retrieved October $17^{\text {th }}$ 2015.

Libal, Autumn. 2004. Namaku Bukan Si Lamba pemuda penyandang tunagrahita, Yogyakarta:Mason Cresh Publisher Inc

Makmun, A.S. 2000. Psikologi Kependidikan. Bandung: PT. Remaja Rosda Karya

Nagaraj, Getha. 1996. English Language Teaching Approach Methods and Technique. India: Orient Longman, Provite Limited.

Parel. M.E. and Jaim P.M. 2008. English Language Teaching (methods, Tool and Technique). Jaipur: Sunrise Publisher and Distributor.

Richards, J. C. \& Rodgers T. S. 2001. Approach and Method in Language Teaching. United Kingdom: Chambridge University Press

Richards, J. C. \& Schimidt, Richards. 2002. Longman Dictionary of Language Teaching and Applied Linguistics third edition. New York: Addison Wesley Longman, Inc.

Richards, J. C. \& Schimidt, Richards. 2010. Longman Dictionary of Language Teaching and Applied Linguistics fourth edition. Malaysia: Pearson Education Limited
Zulfiqar, Saidna bin Tahir. 2012. Teaching English as World Language: Pengajaran Bahasa Inggris. Jakarta. Media Pustaka Qalam 